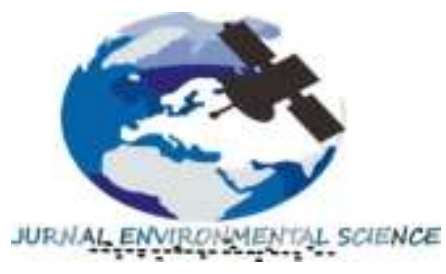

Jurnal Environmental Science

Volume 4 Nomor 1 Oktober 2021

p-ISSN : 2654-4490 dan e-ISSN : 2654-9085

Homepage at : ojs.unm.ac.id/JES

E-mail :jes@unm.ac.id

\title{
PENGARUH ALIH FUNGSI LAHAN TAMBAK KE SAWAH TERHADAP PENDAPATAN KELUARGA TANI KECAMATAN MATTIRO SOMPE KABUPATEN PINRANG
}

\author{
Kasturiyah $^{1}$, Abdul Malik², Sukri Nyompa ${ }^{3}$ \\ ${ }^{123}$ Jurusan Geografi Fakultas Ilmu dan Pengetahuan Alam \\ Universitas Negeri Makassar \\ Email: kasturiyahs@gmail.com ${ }^{1}$,abdulmalik@unm.ac.id ${ }^{2}$
}

\begin{abstract}
This research is motivated by the decline of shrimp production due to the infection of WSSV (White Spot Syndrome Virus) which causes the income of farmers in sub-district of Mattiro Sompe, Pinrang Regency to decrease and change the function of fishpond to ricefield to meet the increasing living needs of the society. The purpose of the research is to determine the size of change and developments of wetland conversion from fishpond to the rice fields in sub-district of Mattiro Sompe from 2002 to 2019 and determine the effect on the income of farmer families in sub-district of Mattiro Sompe in Pinrang regency. This research use descriptive method with a quantitative approach. The result showed that the change of function from fishpond to rice fields in 2002-2019 was 2403.87 Ha with 141.19 Ha or 5.88\% average value of land change each year. The distribution of areas for the change of function from fishpond to rice fields occurred in urban village of Langnga and the villages of Mattombong, Patobong, Samaenre, Massulowalie, Siwolong-polong and Mattiro Tasi. The average income of farmers before and after the change of function of the wetland in 2002-2014 increase from Rp1.181.000,- to Rp2.136.000,- and in 2014-2019 it increases from Rp1.259.000,- to Rp2.016.000,-. Based on SPSS analysis with paired sample t test for hypothesis test result, there is a significant difference between income before and after the change of function of the wetland.
\end{abstract}

Keyword: wetland conversion, effect, and income

\begin{abstract}
ABSTRAK
Penelitian ini dilatarbelakangi oleh penurunan produksi udang karena terinfeksi WSSV (White Spot Syndrome Virus) yang menyebabkan pendapatan petani di Kecamatan Mattiro Sompe Kabupaten Pinrang menurun dan melakukan alih fungsi lahan tambak ke sawah untuk memenuhi kebutuhan hidup yang semakin meningkat. Penelitian ini bertujuan untuk mengetahui besar perubahan dan perkembangan alih fungsi lahan tambak ke sawah di Kecamatan Mattiro Sompe dari tahun 2002 sampai dengan tahun 2019 dan mengetahui pengaruh alih fungsi lahan tambak ke sawah terhadap pendapatan keluarga tani Kecamatan Mattiro Sompe Kabupaten Pinrang. Metode yang digunakan dalam penelitian ini adalah metode deksriptif dengan pendekatan kuantitatif. Hasil penelitian menunjukkan bahwa perubahan lahan tambak ke sawah tahun 2002-2019 sebesar 2403.87 Ha, dengan rata-rata perubahan lahan setiap tahunnya sebesar 141.40 Ha atau sebesar 5.88\%. Penyebaran wilayah alih fungsi lahan tambak ke sawah terjadi di Kelurahan Langnga, Desa Mattombong, Patobong, Samaenre, Massulowalie, Siwolong-polong dan Mattiro Tasi. Rata-rata pendapatan petani sebelum dan setelah alih fungsi lahan tahun 2002-2014 meningkat dari Rp.1.181.000,- menjadi Rp.2.136.000,- dan tahun 2014-2019 meningkat dari Rp.1.259.000,- menjadi Rp.2.016.000,-. Berdasarkan analisis SPSS dengan uji paired sample test dan hasil uji hipotesis terdapat perbedaan yang signifikan antara pendapatan sebelum dan sesudah alih fungsi lahan.
\end{abstract}

Kata Kunci : alih fungsi lahan, pengaruh dan pendapatan 


\section{PENDAHULUAN}

Tahun 1994 Indonesia menjadi produsen udang papan atas di dunia dengan produksi $>300.000$ ton/tahun (tambak intensif sekitar 60\%, tambak sederhana mencapai 20\% dan tambak semi-intensif sekitar 10\%). Mulai tahun 1997 hingga sekarang produksi udang Indonesia mengalami penurunan yang tidak sedikit, yaitu kira-kira produksi pertahun berkisar antara 160.000-200.000 ton (Samsul Bahri,2013).

Kabupaten Pinrang, salah satu Kabupaten di Sulawesi Selatan mempunyai luas lahan tambak sekitar 15.026 Ha dengan hasil produksi 29.650,39 Ton (Ikan Bandeng dan Udang) dan sekitar 99,7\% dari luas tambak tersebut dikelola secara tradisional. Rata-rata kepemilikan lahan petani tambak seluas 0,17 Ha. Pertanian tambak di Kabupaten Pinrang setidaknya meliputi lebih dari 6.000 keluarga petani tambak. Perbandingan antara besarnya jumlah rumah tangga petani tidak sebanding dengan jumlah lahan pertanian yang tersedia, belum lagi jika lahan tidak produktif maka hasil dari mengelola lahan pertanian juga tidak banyak dan tidak mampu mencukupi kebutuhan hidup keluarga (BPS,2017).

Sejak tahun 1998 terjadi gagal panen di petakan tambak secara luas di Kabupaten Pinrang, udang mati karena terinfeksi WSSV (White Spot Syndrome Virus) dan Vibrio (Perikanan, 2015). Tahun 2000-2018 luas tambak Kabupaten Pinrang 15.735 Ha, terjadi penurunan hasil produksi Udang dari 3.379,12 Ton menjadi 2.148,35 Ton dengan nilai produksi Rp233.159.280 turun menjadi Rp79.494.500 (BPS, 2018).

Pada tahun 1980 - 1990-an budidaya udang mengalami keberhasilan. Hal ini ditandai karena daya dukung tambak dan wilayah pesisir yang masih memadai. Akan tetapi seiring dengan penggunaan tambak secara terus-menerus, akhirnya mengakibatkan terjadinya degradasi lingkungan tambak pada khususnya dan wilayah pesisir pada umumnya dalam meregenerasi lingkungannya (Asbar, 2015). lingkungan (Asbar, 2015). Periode 1979 - 2012 laju deforestasi tahunan mangrove sulawesi Selatan berkisar antara 1\% dan 5\% (Malik dkk, 2017), karena itu sangat penting untuk melindungi dan merehabilitasi Kawasan mangrove untuk meningkatkan stok karbon dalam biomassa tanaman untuk mitigasi perubahan iklim (Malik dkk, 2020). Secara bersamaan dengan degredasi dan hilangnya mangrove dikaitkan dengan erosi pantai dan intrusi air asin dan juga dapat menyebabkan penurunan produksi tahunan perikanan dibeberapa daerah (Malik dkk, 2017). Hal ini mengakibatkan penurunan produktivitas tambak yang berdampak pada penurunan produktivitas tambak itu sendiri. Berdasar pada persoalan tersebut mengakibatkan permasalahan pada industri budidaya udang windu nasional yang mengalami stagnasi akibat wabah penyakit yang dipicu oleh degradasi lingkungan (Asbar, 2015).

Pengelolaan tambak apabila ditelusuri dari waktu ke waktu mengalami berbagai permasalahan. Permasalahan tersebut mulai dari rendahnya penguasaan teknologi dan informasi, keterbatasan modal dan lahan, serta semakin buruknya kualitas air, dan infrastruktur saluran air yang tidak memadai. Luas lahan, kualitas air dan tingkat produktifitas tambak pertanian sangat menentukan hasil yang diperoleh petani dari mengelola lahan pertaniannya. (Prasetya, 2015).

Berbagai permasalahan dalam sektor tambak menyebabkan petani tambak di Kecamatan Mattiro Sompe mulai meninggalkan profesinya sebagai petani tambak menjadi petani sawah. Lahan pertanian di Kecamatan Mattiro Sompe mayoritas digunakan sebagai lahan tambak. Pada tahun 2006 hingga 2019 mulai terjadi peralihan lahan pertanian dari tambak menjadi sawah. Berdasarkan hasil observasi awal, petani tambak di Kecamatan Mattiro Sompe mengalihkan tambaknya menjadi sawah karena udang terinfeksi virus WSSV (White Spot Syndrome Virus) yang menyebabkan penurunan hasil panen, ketersediaan air laut terbatas untuk pemenuhan air asin pada tambak karena muara mengalami pendangkalan yang menyebabkan tambak yang jauh dari muara mengalami kekeringan menyebabkan tambak menjadi terkatung-katung atau tidak dikelola dan adanya peningkatan taraf hidup masyarakat yang mendorong kebutuhan ekonomi seperti pemenuhan kebutuhan sehari-hari dan pemenuhan biaya 
sekolah semakin meningkat. Adanya alih fungsi ini secara tidak langsung terjadi perubahan mata pencarian. Perubahan mata pencaharian berhubungan dengan aspek ekonomi.

\section{METODE PENELITIAN}

\section{Jenis Penelitian}

Jenis penelitian yang digunakan adalah metode deksriptif kuantitatif dengan bantuan teknik sistem informasi geografis. Penelitian deksriptif adalah penelitian yang dapat menganalisis serta menyajikan fakta dari suatu objek yang dikaji dengan cara sistematik sehingga objek yang dikaji tersebut dapat lebih mudah untuk dimengerti dan disimpulkan. Penelitian ini menggunakan bantuan teknik system informasi geografis sebagai teknik untuk mengolah dan menganalisis data, serta dilakukan Ground Check di lapangan untuk uji akurasi hasil penelitian atau data yang telah diolah.

\section{Waktu dan Tempat Penelitian}

Penelitian ini dilakukan di Kecamatan Mattiro Sompe, Kabupaten Pinrang. Penelitian ini dimulai pada Bulan Desember-Maret 2020.

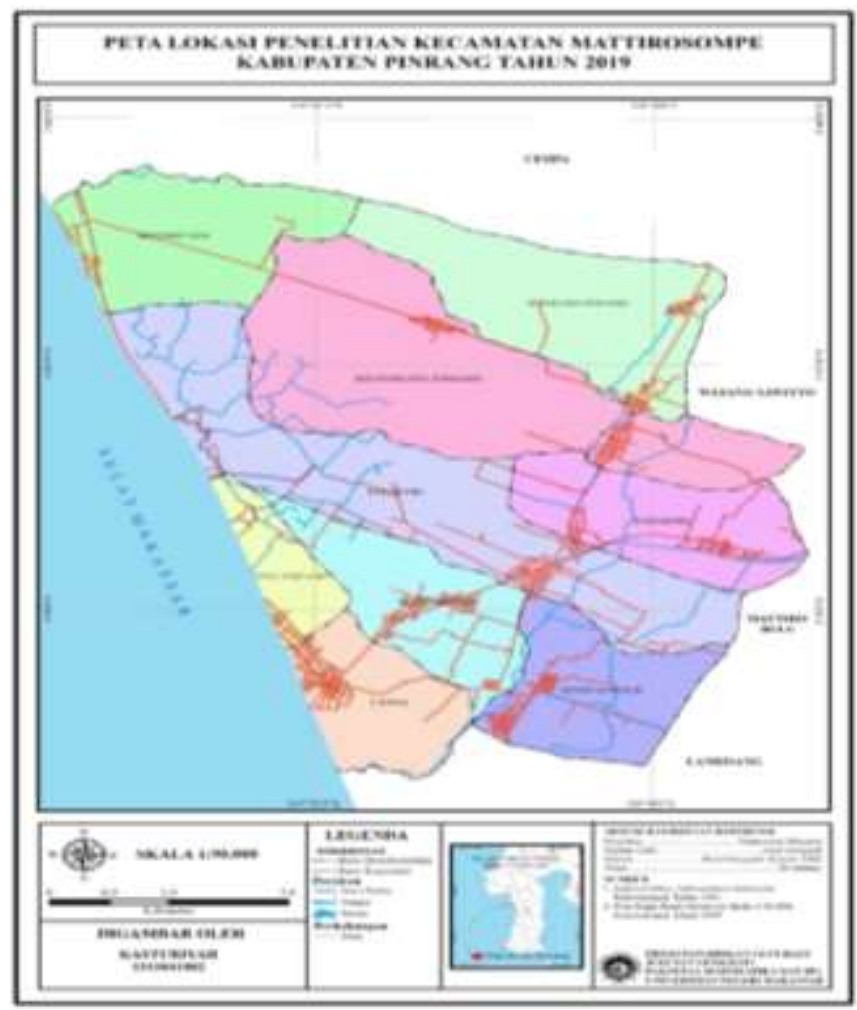

Gambar 1. Peta Lokasi Penelitian

\section{Sumber Data}

Penentuan jumlah sampel penelitian menggunakan teknik Slovin (Sugiyono,2011) dan penentuan informan menggunakan purposive sampling yakni pengambilan sumber data (informan) berdasarkan pertimbangan tertentu (Sugiyono,2016). Dalam hal ini peneliti menetapkan informan yang mengelola sendiri lahan sawahnya. Informan diwawancara dengan menggunakan guide interview atau pedoman wawancara yang telah dipersiapkan sebelumnya.

\section{Teknik Pengumpulan Data}

Dalam mengumpulkan data, ada 3 teknik yang di gunakan oleh penelitian ini, yaitu teknik observasi, wawancara dan dokumentasi. 


\section{Teknik Analisis Data}

1. Analisis Statistik Deksriptif, menggunakan rumus presentase untuk mempresentasekan hasil wawancara informan.

2. Analisis Statistik Inferensial, menggunakan Uji Paired Sample t test menggunakan aplikasi SPSS.

3. Analisis Peta Citra, menggunakan aplikasi Envi dan ArcGis.

Penelitian ini menggunakan metode klasifikasi terbimbing Maximum Likelihood classification (MLC). Metode ini membutuhkan training area sebagai penetapan sampel-sampel kelas yang akan digunakan. Pemrosesan klasifikasi akan dilakukan menggunakan software Envi. Pada software tersebut training area yang akan dibuat akan ditampung ke dalam file ROI (Region Of Interest).

\section{HASIL DAN PEMBAHASAN}

\section{Hasil}

\section{Besar Perubahan dan Perkembangan Alih Fungsi Lahan Tambak Ke Sawah Di Kecamatan Mattiro Sompe Dari Tahun 2002 Sampai Dengan Tahun 2019}

\section{Penggunaan lahan Tahun 2002, 2014 dan 2019}

Penggunaan lahan Kecamatan Mattiro Sompe secara spasial disajikan pada peta penggunaan lahan Kecamatan Mattiro Sompe. Hasil interpretasi penggunaan lahan di Kecamatan Mattiro Sompe dari Citra Landsat mengelompokkan penggunaan lahan menjadi tiga jenis penggunaan lahan yaitu tambak, sawah, dan non tambak dan sawah.

\section{Alih fungsi lahan tambak ke sawah Tahun 2002, 2014 dan 2019}

Peta perubahan lahan tambak ke sawah di Kecamatan Mattiro Sompe disajikan pada Gambar 2, 3 dan 4. Luas tiap penggunaan lahan di Kecamatan Mattiro Sompe pada tahun 2002, 2014 dan 2019 disajikan dalam Tabel 1, 2 dan 3.

Tabel 1. Luas penggunaan lahan Kecamatan Mattiro Sompe tahun 2002-2014

\begin{tabular}{clccc}
\hline \multirow{2}{*}{ No } & \multicolumn{1}{|}{ Lahan/Tahun } & \multicolumn{2}{c}{ Luas (Ha) } & $\begin{array}{c}\text { Luas Perubahan } \\
\text { (Ha) }\end{array}$ \\
\cline { 3 - 4 } $\mathbf{1}$ & Non tambak dan non sawah & $1.878,51$ & $1.522,70$ & 345,81 \\
$\mathbf{2}$ & Sawah & 1971,05 & $4.255,29$ & $2.284,24$ \\
$\mathbf{3}$ & Tambak & $5.089,85$ & $3.16, .42$ & $1.928,43$ \\
\hline & Total & $\mathbf{8 9 3 9 , 4 1}$ & $\mathbf{8 . 9 3 9 , 4 1}$ & $\mathbf{4 5 5 8 , 4 8}$ \\
\hline
\end{tabular}

Tabel 2. Luas penggunaan lahan Kecamatan Mattiro Sompe tahun 2014-2019

\begin{tabular}{|c|c|c|c|c|}
\hline \multirow{2}{*}{ No } & \multirow{2}{*}{ Lahan/Tahun } & \multicolumn{2}{|c|}{ Luas (Ha) } & \multirow{2}{*}{$\begin{array}{c}\text { Luas Perubahan } \\
\text { (Ha) }\end{array}$} \\
\hline & & 2014 & 2019 & \\
\hline 1 & Non tambak dan non sawah & $1.522,70$ & $1.178,81$ & 343,89 \\
\hline 2 & Sawah & $4.255,29$ & $5.545,46$ & $1.290,17$ \\
\hline 3 & Tambak & $3.161,42$ & $2.215,14$ & 946,28 \\
\hline & Total & 8.939.41 & 8.939.41 & $2.580,34$ \\
\hline
\end{tabular}


Tabel 3. Luas penggunaan lahan Kecamatan Mattiro Sompe tahun 2014-2019

\begin{tabular}{llccc}
\hline \multirow{2}{*}{ No } & \multirow{2}{*}{ Lahan/Tahun } & \multicolumn{2}{c}{ Luas (Ha) } & Luas Perubahan \\
\cline { 3 - 4 } & & 2002 & 2019 & $($ Ha) \\
\hline $\mathbf{1}$ & Non tambak dan non sawah & $1.878,51$ & $1.178,81$ & $3.057,32$ \\
$\mathbf{2}$ & Sawah & $1.971,05$ & $5.545,46$ & $3.574,41$ \\
$\mathbf{3}$ & Tambak & $5.089,85$ & $2.215,14$ & $2.874,71$ \\
\hline \multirow{2}{*}{ Total } & $\mathbf{8 . 9 3 9 , 4 1}$ & $\mathbf{8 . 9 3 9 , 4 1}$ & $\mathbf{9 . 5 0 6 , 4 4}$ \\
\hline
\end{tabular}

Penggunaan lahan terbesar pada tahun 2002 di Kecamatan Mattiro Sompe adalah lahan tambak seluas 5.089,85 ha dan pada tahun 2014 dan 2019 mengalami penurunan. Penggunaan lahan terbesar 2014 dan 2019 adalah lahan sawah, peningkatan ini karena adanya alih fungsi lahan tambak ke sawah. Alih fungsi lahan tambak ke sawah. Perubahan lahan Kecamatan Mattiro Sompe tahun 2002-2014, 2014-2019 dan 2002-2019 disajikan pada Tabel 4, 5 dan 6.

Tahun 2002-2014 di Kecamatan Mattiro Sompe sebesar 1570.7 Ha atau $18.14 \%$ dari keseluruhan perubahan lahan. Tahun 2014-2019 sebesar 708.69 Ha atau 31.01\% dari keseluruhan perubahan lahan dan tahun 2002-2019 sebesar 2403.87 Ha atau sebesar 48.24\% dari keseluruhan perubahan penggunaan lahan yang terjadi selama 17 tahun.

Tabel 4. Matriks perubahan lahan Kecamatan Mattiro Sompe tahun 2002-2014

\begin{tabular}{ccccc}
\hline \multirow{2}{*}{ No } & Luas Penggunaan & \multicolumn{3}{c}{ Luas Penggunaan Lahan 2014 (Ha) } \\
\cline { 3 - 5 } & Lahan 2002 (Ha) & Non & Sawah & Tambak \\
\hline $\mathbf{1}$ & Non & 354,98 & $1.166,94$ & 356,68 \\
$\mathbf{2}$ & Sawah & 389,19 & $1.515,75$ & 65,59 \\
$\mathbf{3}$ & Tambak & 779,87 & $\mathbf{1 . 5 7 0 , 7}$ & $2.739,6$ \\
\hline
\end{tabular}

Tabel 5. Matriks perubahan lahan Kecamatan Mattiro Sompe tahun 2014-2019

\begin{tabular}{llccc}
\hline No & $\begin{array}{c}\text { Luas } \\
\text { Penggunaan } \\
\text { Lahan 2014 } \\
(\mathbf{H a})\end{array}$ & \multicolumn{3}{c}{ Luas Penggunaan Lahan 2019(Ha) } \\
& Non & Sawah & Tambak \\
$\mathbf{1}$ & Non & 571,73 & 705,78 & 245,18 \\
$\mathbf{2}$ & Sawah & 106,21 & $4.130,91$ & 18,17 \\
$\mathbf{3}$ & Tambak & 500,97 & $\mathbf{7 0 8 , 6 9}$ & $1.951,76$ \\
\hline
\end{tabular}


Tabel 6. Matriks perubahan lahan Kecamatan Mattiro Sompe tahun 2002-2019

\begin{tabular}{llccc}
\hline & \multirow{2}{*}{$\begin{array}{c}\text { Luas } \\
\text { No }\end{array}$} & \begin{tabular}{c} 
Penggunaan \\
Lahan 2002 \\
\cline { 3 - 5 }
\end{tabular} & \multicolumn{3}{c}{ Luas Penggunaan Lahan 2019 (Ha) } \\
\cline { 3 - 5 } & Non & 251,93 & $1.511,52$ & Tambak \\
\hline $\mathbf{1}$ & Son & $1.626,94$ & 23,01 \\
\hline $\mathbf{2}$ & Sawah & 320,68 & $\mathbf{2 . 4 0 3 , 8 7}$ & $2.078,21$ \\
\hline $\mathbf{3}$ & Tambak & 608,86 & & \\
\hline
\end{tabular}

Adapun perubahan lahan di Kecamatan Mattiroseompe Kabupaten Pinrang dapat dilihat pada gambar di bawah ini:

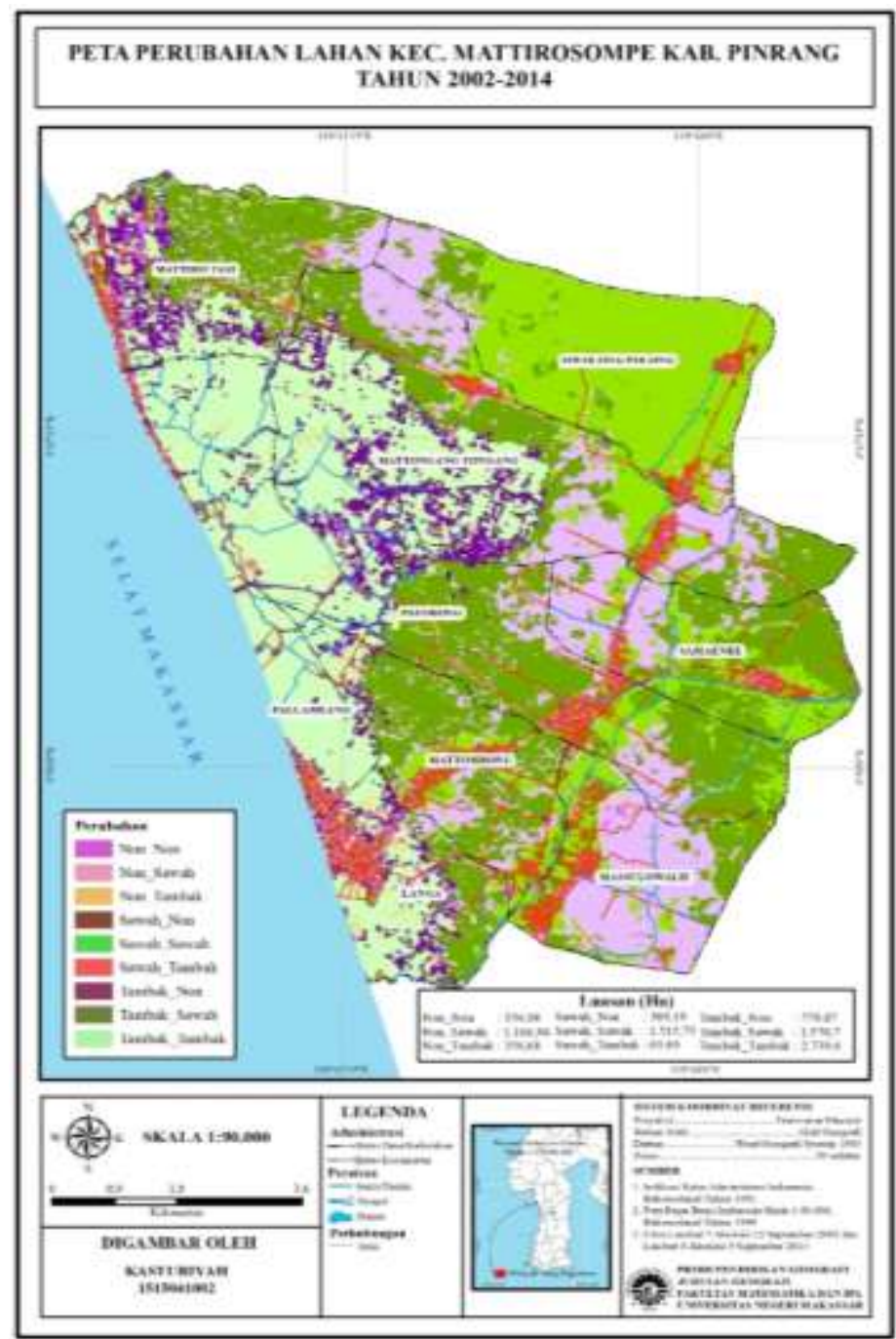

Gambar 2. Peta perubahan lahan Kecamatan Mattiro Sompe tahun 2002-2014 
PETA PERUBAHAN LAHAN KEC. MATTIROSOMPE KAB. PINRANG TAHUN 2014-2019
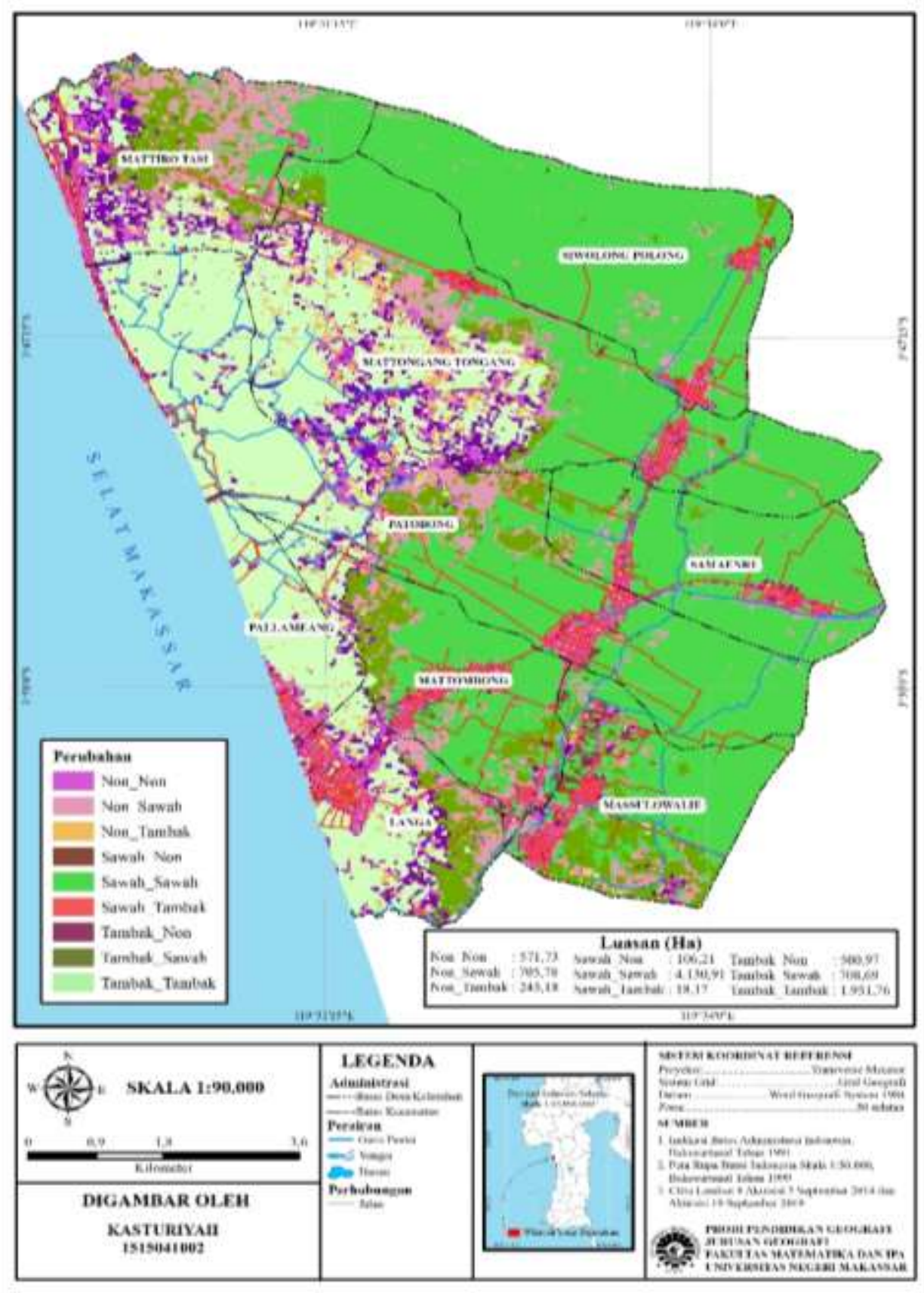

Gambar 3. Peta perubahan lahan Kecamatan Mattiro Sompe tahun 2014-2019 


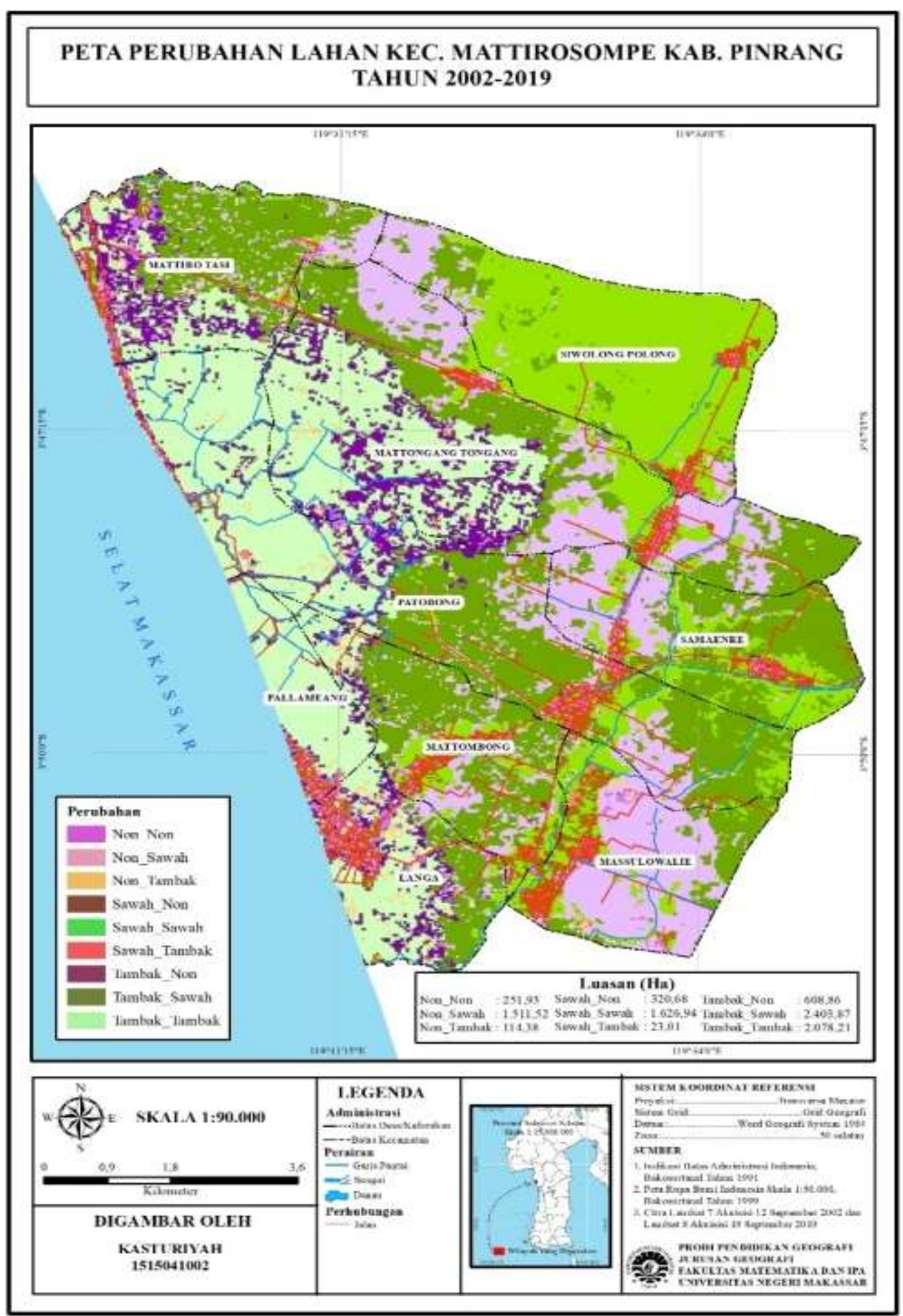

Gambar 4. Peta perubahan lahan Kecamatan Mattiro Sompe tahun 2002-2019

2. Mengetahui Pengaruh Alih Fungsi Lahan Tambak Ke Sawah Terhadap Pendapatan Keluarga Tani Kecamatan Mattiro Sompe Kabupaten Pinrang.

\section{Modal pengelolaan lahan}

a. Modal pengelolaan lahan alih fungsi tahun 2002-2014 periode 1

Petani yang mengalihfuhsikan lahannya pada tahun 2002-2014 dalam mengolah tambak untuk satu periode (1 tahun) antara $\leq$ Rp.2.000.000,- berjumlah 8 petani dengan nilai persentase sebesar $28.57 \%$ dan biaya yang digunakam antara Rp.2.000.001,- Rp.15.000.000,- berjumlah 20 orang dengan nilai persentase sebesar $71.42 \%$.

b. Modal pengelolaan lahan alih fungsi tahun 2002-2014 periode 2

Jumlah responden terbesar menggunakan modal antara Rp.2.000.001,- - Rp.15.000.000,- 
dengan luas lahan sawah 0.3 - 1 ha, nilai persentase sebesar $3.57 \%$ dan jumlah responden paling sedikit menggunkan modal paling antara Rp.67.000.001,- - Rp.80.000.000,- dengan luas lahan 3.5 ha, nilai persentase sebesar $3.57 \%$

c. Modal pengelolaan lahan alih fungsi tahun 2014-2019 periode 1

Petani yang mengalihfuhsikan lahannya pada tahun 2014-2019 dalam mengolah tambak untuk satu periode ( 1 tahun) antara $\leq$ Rp.2.000.000,- berjumlah 16 petani dengan nilai persentase sebesar $26.22 \%$ dan biaya yang digunakam antara Rp.2.000.001,- - Rp.15.000.000,- berjumlah 45 orang dengan nilai persentase sebesar $73.77 \%$.

d. Modal pengelolaan lahan alih fungsi tahun 2014-2019 periode 2

Jumlah responden terbesar menggunakan modal antara Rp.2.000.001,- - Rp.15.000.000,- dengan nilai persentase sebesar $66.29 \%$ dan jumlah responden paling sedikit menggunakan modal paling antara Rp.15.000.001,- - Rp.28.000.000,- dengan nilai persentase sebesar 30.33\%.

\section{Tingkat pendapatan}

1. Tingkat pendapatan petani sebelum dan setelah alih fungsi lahan tahun 2002-2014 periode 1 Pendapatan petani sebelum alih fungsi lahan dominan berkisar antara Rp.500.001,- Rp.2.000.000,- atau sebesar 57.14\% dan setelah alih fungsi lahan dominan berkisar antara Rp.500.001,- - Rp.2.000.000,- atau sebesar 46.06\% dan Rp.2.000.001,- - Rp.3.500.000,- atau $34.83 \%$.

2. Tingkat pendapatan petani sebelum dan setelah alih fungsi lahan tahun 2002-2014 periode 2 Pendapatan petani sebelum alih fungsi lahan dominan berkisar antara Rp.500.001,- Rp.2.000.000,- atau sebesar 57.14\% dan setelah alih fungsi lahan dominan berkisar antara Rp.500.001,- - Rp.2.000.000,- atau sebesar 39.28\% dan Rp.2.000.001,- - Rp.3.500.000,- atau $35.71 \%$. Pendapatan pada periode 2 mengalami peningkatan yang tinggi karena modal pengelolahan lahan sawah tidak sebesar modal periode 1 dan lahan sawah mulai menyesuaikan

3. Tingkat pendapatan petani sebelum dan setelah alih fungsi lahan tahun 2014-2019 periode 1 Pendapatan petani sebelum alih fungsi lahan dominan berkisar antara Rp.500.001,- Rp.2.000.000,- atau sebesar $60.65 \%$ dan setelah alih fungsi lahan dominan berkisar antara Rp.500.001,- - Rp.2.000.000,- atau sebesar 47.54\% dan Rp.2.000.001,- - Rp.3.500.000,- atau $36.06 \%$.

4. Tingkat pendapatan petani sebelum dan setelah alih fungsi lahan tahun 2014-2019 periode 2 Pendapatan petani sebelum alih fungsi lahan dominan berkisar antara Rp.500.001,- Rp.2.000.000,- atau sebesar $60.65 \%$ dan setelah alih fungsi lahan dominan berkisar antara Rp.2.000.001,- - Rp.3.500.000,- atau 40.98\%. Pendapatan pada periode 2 mengalami peningkatan yang tinggi karena modal pengelolahan lahan sawah tidak sebesar modal periode 1 dan lahan sawah mulai menyesuaikan

\section{Analisis inferensial uji paired sample t test}

Berdasarkan pendapatan keluarga tani sebelum dan sesudah alih fungsi lahan tambak ke sawah pada hasil uji paired sample t test didapatkan hasil bahwa nilai dari signifikan Sig berjumlah 0.000 dimana pada dasar pengambilan keputusan jika nilai Sig.(2-tailed) < dari 0.05 maka terdapat perbedaan yang signifikan antara $\mathrm{X}$ dan $\mathrm{Y}$, dimana $\mathrm{X}$ diartikan sebelum alih fungsi lahan tambak kesawah dan simbol Y diartikan setelah alih fungsi lahan tambak kesawah. Sebaliknya jika nilai Sig.(2-tailed) $>$ dari 0.05 maka tidak terdapat perbedaan yang signifikan antara nilai $\mathrm{X}$ dan $\mathrm{Y}$.

Pada pengujian hipotesis (uji-t) dengan menggunakan paired samples test dapat diperoleh bahwa $t_{\text {hitung }}$ sebesar -11.06 dengan $t_{\text {tabel }}$ untuk uji dua pihak sebesar 1,97 dan taraf signifikasi $\alpha=$ $5 \%$. Karena $t_{\text {hitung }}(-11.06) \leq t_{\text {tabel }}$ (1.97) maka $H_{0}$ ditolak. Berdasarkan uji hipotesis, dapat disimpulkan bahwa terdapat perbedaan rata-rata pendapatan sebelum dan setelah alih fungsi lahan tambak ke sawah keluarga tani di Kecamatan Mattiro Sompe dengan taraf signifikasi sebesar 0.05 atau sebesar 5\%. Dari hasil analisis dengan menggunakan uji t maka dengan demikian dapat disimpulkan bahwa alih fungsi lahan mempengaruhi pendapatan keluarga tani di Kecamatan Mattiro Sompe, Kabupaten Pinrang. 


\section{Karakteristik responden}

a. Berdasarkan tahun alih fungsi lahan jumlah responden terbesar adalah alih fungsi lahan tahun 2014-2019 sebanyak 61 otang atau $68.53 \%$ sedangkan $2002-2014$ sebanyak 28 orang atau $31.46 \%$.

b. Berdasarkan umur Jumlah responden terbesar adalah responden yang berumur antara 36 - 44 tahun yakni sebanyak 27 atau sebesar $30.33 \%$ sedangkan responden paling sedikit berumur $63>$ tahun yaitu sebanyak 5 orang atau sebesar $5.61 \%$.

c. Berdasarkan tingkat Pendidikan jumlah responden terbesar adalah responden dengan Pendidikan terakhir SMP yakni 31 orang atau sebesar $34.83 \%$ dan SMA yakni 32 orang atau sebesar $35.95 \%$ sedangkan responden paling sedikit dengan Pendidikan terkahir S2 yakni 1 orang atau sebesar $1.12 \%$.

d. Berdasarkan jumlah tanggungan

jumlah responden paling besar adalah dengan tanggungan antara $3-5$ orang yakni 52 orang atau sebesar $58.42 \%$ dan jumlah responden paling sedikit adalah dengan tanggungan $6 \geq$ orang yakni 1 orang atau sebesar $1.12 \%$ responden.

\section{Pembahasan \\ 1. Besar Perubahan dan Perkembangan Alih Fungsi Lahan Tambak Ke Sawah Di Kecamatan Mattiro Sompe Dari Tahun 2002 Sampai Dengan Tahun 2019}

Perubahan lahan tambak tahun 2002-2019 sebesar 2874.71 Ha (tabel 4.4) atau sebesar 30.23\% (tabel 4.4) dan perubahan lahan sawah tahun 2002-2019 sebesar 3574.41 Ha atau sebesar 37.59\% dari keseluruhan perubahan lahan yang terjadi (tabel 4.4). Pada tabel 4.10 dilihat bawah perubahan lahan tambak ke sawah tahun 2002-2019 sebesar 2403.87 Ha atau 34.49\% dengan rata-rata perubahan lahan setiap tahunnya $141.40 \mathrm{Ha}$ atau $5.88 \%$ setiap tahun.

Penyebaran wilayah alih fungsi lahan tambak ke sawah terjadi di Kelurahan langnga, Desa Mattombong, Patobong, Samaenre, Massulowalie, Siwolong-polong dan Mattirotasi. Pengalihan lahan tambak ke sawah menggunakan alat berat (Excavator) dengan biaya sewa Rp.500.000, sampai Rp. 600.000/jam dan lama pengerjaan setiap lahan berbeda, tergantung keadaan lahan. $1 \mathrm{Ha}$ tambak membutuhkan waktu 9 sampai 15 jam pengerjaan.

Perkembangan alih fungsi lahan tambak ke sawah dari tahun 2002-2019 atau 17 tahun belakangan ini cukup pesat, alih fungsi lahan tambak ke sawah tahun 2002-2014 sebesar $1570.7 \mathrm{Ha}$ atau $65.34 \%$ dengan rata-rata $120.82 \mathrm{Ha}$ atau $7.69 \%$ setiap tahunnya dan alih fungsi lahan tambak ke sawah tahun 2014-2019 sebesar $708.69 \mathrm{Ha}$ atau $29.48 \%$ dengan rata-rata $118.11 \mathrm{Ha}$ atau $16.66 \%$. Perubahan lahan ini terjadi di Kelurahan Langnga, Desa Mattombong, Massulowalie, Patobong, Samaenre, Mattongang-tongang, Siwolong-polong dan Mattiro Tasi.

Rata-rata alih fungsi lahan tertinggi terjadi pada tahun 2002-2014, mencapai 120.82 ha/tahun, rata-rata perubahan ini lebih tinggi dari tahun 2014-2019. Tingginya perubahan ini disebabkan karena petani melihat keberhasilan petani lainnya yang lebih dulu melakukan alih fungsi lahan. Hal ini dikuatkan oleh hasil penelitian Afandi (2018), bahwa Sebagian pelaku alih fungsi lahan tambak menjadi sawah hanya mengikut dengan kondisi lingkungan sekitar yang ada dan melihat perkembangan dari tambak dan sawah. Dalam kurun waktu 17 tahun, 2.403,87 Ha lahan tambak menjadi sawah dan sampai saat penelitian ini dilakukan alih fungsi lahan tambak masih terus dilakukan oleh petani di Kecamatan Mattiro Sompe Kabupaten Pinrang.

\section{Pengaruh alih fungsi lahan tambak ke sawah terhadap pendapatan keluarga tani Kecamatan Mattiro Sompe}

Penggunaan lahan merupakan segala macam bentuk campur tangan manusia terhadap lahan dalam upaya pemenuhan kebutuhan hidupnya. Perubahan lahan tambak ke sawah merupakan upaya petani dalam pemenuhan kebutuhan hidupnya, penurunan hasil produksi dan harga udang menyebabkan pendapatan keluarga tani mengalami penurunan dan bahkan ada yang mengalami kerugian akibat gagal panen. Diawal alih fungsi lahan hasil produksi padi rendah karena lahan masih dalam tahap penyesuaian. 
Perubahan lahan tambak ke sawah tahun 2002 sampai 2019 sebesar 2.403.87 Ha. Modal yang dibutuhkan dalam memulai usaha pengolahan lahan sawah tidak sedikit dimana satu hektar tambak membutuhkan biaya sewa excavator 5 juta atau lebih dari itu tergantung dengan lama pengerjaan lahan dan ditambah modal untuk bibit, pupuk, dan pestisida. Modal ini jauh lebih besar dari modal pengolahan lahan tambak tetapi pendapatan dari hasil produksi padi lebih tinggi dari hasil produksi ikan dan udang.

Pendapatan petani periode 1 adalah pendapatan petani dari hasil produksi padi musim pertama setelah alih fungsi lahan, hasil produksi padi belum stabil dan petani membutuhkan modal yang besar sehingga pendapatannya belum tinggi. Pendapatan petani periode 2 adalah pendapatan petani dari hasil produksi padi musim kedua setelah alih fungsi lahan, hasil produksi mulai stabil dan petani tidak membutuhkan modal sebanyak musim pertama.

Peningkatan rata-rata pendapatan petani setelah alih fungsi lahan tahun 2002-2014 periode 1 sebesar Rp.947.000,- atau 3.57\% dan periode 2 sebesar Rp.1.369.000,- atau 3.56\%. Peningkatan ratarata pendapatan petani setelah alih fungsi lahan tahun 2014-2019 periode 1 sebesar Rp.714.000,- atau $1.6 \%$ dan periode 2 sebesar Rp.1.292.000,- atau 1.6\% (lampiran D). Hal ini menunjukkan pengaruh alih fungsi lahan terhadap pendapatan karena adanya alih fungsi lahan ini pendapatan keluarga tani dapat meningkat.

Berdasarkan pendapatan sebelum dan sesudah alih fungsi lahan tambak ke sawah pada hasil uji paired sample $t$ test dan uji hipotesis, terdapat perbedaan yang signifikan antara pendapatan sebelum dan seseudah alih fungsi lahan. Dari analisis tersebut dapat disimpulkan bahwa alih fungsi lahan tambak ke sawah berpengaruh terhadap pendapatan keluarga tani di di Kecamatan Mattiro Sompe, Kabupaten Pinrang.

\section{SIMPULAN DAN SARAN}

Kesimpulan yang dapat diambil adalah alih fungsi lahan tambak ke sawah dari tahun 20022019 atau 17 tahun belakangan ini sebesar $2403.87 \mathrm{Ha}$ atau sebesar $34.49 \%$. Rata-rata alih fungsi lahan tambak ke sawah tahun 2002-2014 sebesar 120.82 Ha/tahun sedangkan tahun 2014-2019 sebesar $118.11 \mathrm{Ha} /$ tahun, terjadi penurunan rata-rata alih fungsi lahan, hal ini terjadi karena ketersediaan lahan yang berpotensi untuk dialihkan mulai berkurang dan lahan tambak yang tersisa berdekatan dengan garis pantai.

Pendapatan petani sebelum dan setelah alih fungsi lahan tahun 2002-2014 meningkat dari Rp.1.181.000,- menjadi Rp.2.136.000,-atau sebesar 3.5\% dan tahun 2014-2019 meningkat dari Rp.1.259.000,- menjadi Rp.2.016.000 atau sebesar 1.6\%. Hal ini menunjukkan adanya pengaruh alih fungsi lahan terhadap pendapatan keluarga tani di Kecamatan Mattiro Sompe dan berdasarkan hasil uji paired sample t test, uji hipotesis terdapat perbedaan yang signifikan antara pendapatan sebelum dan setelah alih fungsi lahan.

\section{DAFTAR RUJUKAN}

Asbar, M. A. 2015. Analisis Kelayakan Bioteknik Dalam Pengembangan Budidaya Tambak Pada Lahan Marginal (Studi Kasus Desa Wiringtasi, Tasiwalie, dan Lotangsalo. Kecamatan Suppa, Kabupaten Pinrang). Universitas Hasanuddin. Makassar.

Badan Pusat Statistik. 2018. Kabupaten Pinrang Dalam Angka 2017. Kabupaten Pinrang : Badan Statistik Pinrang. . (2017). Kabupaten Pinrang Dalam Angka 2016 Kabupaten Pinrang : Badan Statistik Pinrang

Malik A, Mertz O, Fensholt R. (2017). Mangrove Forest Deckine: Consequences for Livelihoods and Environment in South Sulawesi. Regional Environmental Change 17 : 157-169.

Malik A, Jalil, A. R, Arifuddin, A., \& Syamsuddin, A. 2020. Biomass Carbon Stocks In The Mangrove Rehabilitated Area Of Sinjai District, South Sulawesi, Indonesia. Geography, Environment, Sustainability, 13(3), 32-38. 
Prasetya, D. 2015. Dampak Alih Funggsi Lahan Dari Sawah Ke Tambak Terhadap Mata Pencaharian Masyarakat Desa (Studi Kasus Di Desa Cebolek Kidul Kecamatan Margoyoso Kab, Pati. Universitas Negari Semarang : Semarang.

Sugiyono. 2011. Metode Penelitian pendidikan pendekatan kuantitatif, kualitatif dan $R \& D$. Bandung: Alfabeta.

Sugiyono. 2016. Metode Penelitian Kuantitatif, Kualitatif dan R\&D. Bandung: PT Alfabet. 